M.M. ALdAYA

A.Y. HOEKSTRA

J.A. AlLan

MARCH 2008

\section{STRATEGIC IMPORTANCE OF}

GREEN WATER IN INTERNATIONAL

CROP TRADE 



\title{
STRATEGIC IMPORTANCE OF GREEN WATER \\ IN INTERNATIONAL CROP TRADE
}

\author{
M.M. AldaYA ${ }^{1}$ \\ A.Y. HOEKSTRA ${ }^{2}$ \\ J.A. ALLAN ${ }^{3}$
}

MARCH 2008

Value of Water Research Report Series No. 25

\footnotetext{
${ }^{1}$ Department of Geodynamics. Complutense University of Madrid, Spain, e-mail: maite_m_aldaya@geo.ucm.es

2 Dept. of Water Engineering and Management, University of Twente, Enschede, The Netherlands

${ }^{3}$ London Water Research Group, King's College \& SOAS, University of London, UK
}

The Value of Water Research Report Series is published by UNESCO-IHE Institute for Water Education, Delft, the Netherlands in collaboration with

University of Twente, Enschede, the Netherlands, and Delft University of Technology, Delft, the Netherlands 



\section{CONTENTS}

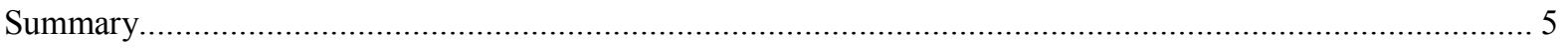

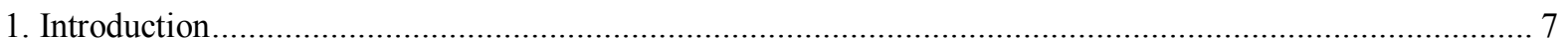

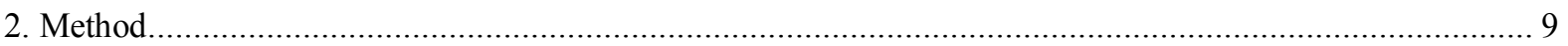

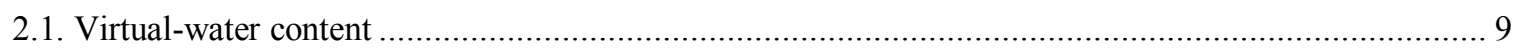

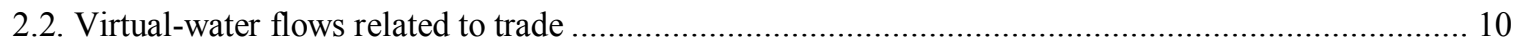

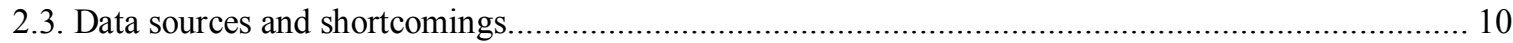

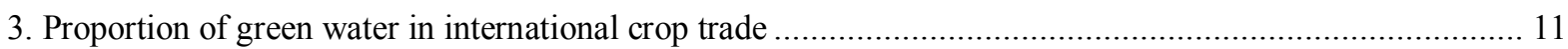

3.1. Virtual-water content of maize, soybean and wheat in the major exporting countries ..................... 11

3.2. Water use for export in the major exporting countries ........................................................ 14

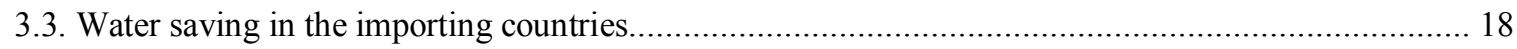

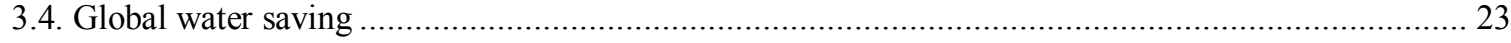

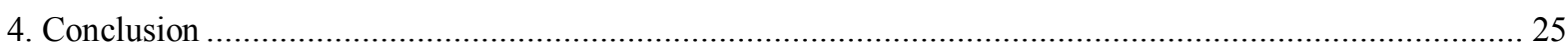

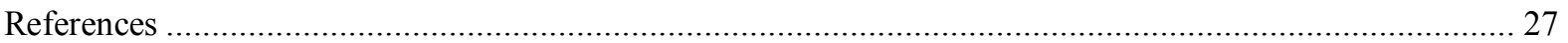





\section{Summary}

Virtual water is the volume of water used to produce a commodity or service. By importing agricultural commodities and the virtual water embedded in them, a country saves the water it would have required to produce those commodities domestically. Virtual-water 'trade', thus, has the potential to relieve water stress and improve water security.

The present research critically evaluates the strategic importance and implications of green water (soil water) in relation to international crop trade. Even if, traditionally, emphasis has been given to irrigation systems, today most global crop production is rain-fed. Besides having a lower opportunity cost, green water use for the production of crops is considered more sustainable than the use of blue water (irrigation). Although green water represents the largest share of virtual water in the international trade of agricultural commodities, with exports going from highly productive rain-fed rich countries towards generally blue water based ones, green water volumes have rarely been estimated.

The present study corroborates that green water is by far the largest share of virtual water embodied in maize, soybean and wheat exports from the USA, Canada, Australia and Argentina during the period 2000-2004. Accordingly, green virtual-water flows can play a major role in ensuring water security and saving water in water-deficit economies. The potential of international green virtual-water 'trade' for saving water and improving water security, however, is constrained by factors such as technology, the potential for further increases in the productivity, the level of socio-economic development, national food policies and international trade agreements. 



\section{Introduction}

There is a growing body of literature focusing on the concept of virtual water and on its potential contribution to saving water and ensuring water security, specially in water-short nations (Hoekstra, 2003; Hoekstra and Chapagain, 2008). Few of them, however, focus on the strategic importance of green water (soil water) in relation to international commodity trade (De Fraiture et al., 2004; Allan, 2006; Chapagain et al., 2006b; CAWMA, 2007).

The virtual-water content of a product (a commodity, good or service) refers to the volume of water used in its production (Allan, 1997; 1999; Hoekstra, 1998). Building on this concept, virtual-water 'trade' represents the amount of water embedded in products traded internationally (Hoekstra, 2003; Hoekstra and Hung, 2002; 2005). International trade can save water globally if a water-intensive commodity is traded from an area where it is produced with high water productivity (resulting in products with low virtual-water content) to an area with lower water productivity (Oki and Kanae, 2004; De Fraiture et al., 2004; Chapagain et al., 2006a; Yang et al., 2006). Thus, a nation can preserve its domestic water resources by importing a water intensive product instead of producing it domestically. This is particularly relevant to arid or semi-arid countries with scarce water resources.

It is important to establish whether the water used proceeds from rainwater evaporated during the production process (green water) or surface or groundwater evaporated as a result of the production of the product (blue water) (Falkenmark, 2003). Traditionally, emphasis has been given to the concept of blue water by focussing on the "miracle" of irrigation systems. However, an increasing number of authors highlight the importance of green water (Rockström, 2001; Falkenmark and Rockström, 2004; Allan, 2006; CAWMA, 2007). It is more and more upheld that green water represents the largest share of virtual water in the international trade of agricultural commodities, with exports going from green water rich countries towards generally blue water based economies. As the use of green water in the production of crops is considered more sustainable than the use of blue water, upgrading the green water concept could contribute to better informed decisions on the efficient allocation and use of water resources.

Even if recent studies emphasise the importance of green water on ensuring water and water-dependent food security through sustaining rain-fed crop production (Falkenmark and Rockström, 2004; CAWMA, 2007; Rockström et al., 2007), hitherto, green water volumes have rarely been estimated. The present research analyses the current importance of green water within international agricultural crop trade.

This research builds on earlier studies, which roughly estimated the share of green water in global agricultural production (Rockström et al., 1999; Chapagain and Hoekstra, 2004; De Fraiture et al., 2004). Chapagain et al. (2006b) have carried out detailed calculations of the green water volumes for cotton production. The present work complements these studies estimating the green and blue virtual-water content of maize, soybean and wheat exports from the USA, Canada, Argentina and Australia, which are the main exporting countries of these crops. 
The report is structured as follows. The method of the research is described in Section 2. Section 3 first estimates the proportion of green and blue water embedded in the selected commodities and countries during 2000-2004. It then analyses virtual-water exports from the exporting countries, virtual-water savings in the importing countries and water savings from a global point of view. The final section concludes that green water use is the bulk of virtual water in the present international trade in maize, soybean and wheat for major exporting countries, and that global and national water and food security is influenced by several factors, being trade barriers, the level of socio-economic development and the type of regulatory policy within each country among the most important. 


\section{Method}

This study quantifies both the green and blue water components of the virtual-water content of maize, soybeans and wheat exports from the USA, Canada and Argentina and of wheat exports from Australia over the period 2000-2004. Although the chosen crops do not have the highest embedded water contents, they do use the most water globally after rice (rice 21 per cent, wheat 12, maize 9 and soybean 4) (Hoekstra and Chapagain, 2007b; 2008). Major exporting countries were chosen for the study: USA, Argentina and Canada contributing 69 per cent to the global exported maize, 63 per cent to soybeans and, together with Australia, 49 per cent to wheat (Table 1). The volume of virtual-water 'trade' depends upon the virtual-water content of the product traded and the physical volume of trade.

\subsection{Virtual-water content}

The virtual-water content of a product is calculated using the methodology developed by Hoekstra and Hung (2002; 2005) and Hoekstra and Chapagain $(2007 b ; 2008)$. The virtual-water content of primary $\mathrm{crops}\left(\mathrm{m}^{3} / \mathrm{ton}\right)$ has been calculated as the ratio of the volume of water used during the entire period of crop growth (crop water requirement, $\mathrm{m}^{3} / \mathrm{ha}$ ) to the corresponding crop yield (ton/ha) in the producing country. The volume of water used to grow crops in the field has two components: effective rainfall (green water) and irrigation water (blue water).

The total crop water requirement, together with the effective rainfall and irrigation requirements per country have been estimated using the CROPWAT model (Allen et al., 1998; FAO, 2003a). The calculation has been done using climate data for the major crop-producing states or provinces (Table 1) and a specific cropping pattern for each crop according to the type of climate. The climate data have been taken from the CLIMWAT database (FAO, 2003b) for the most appropriate climatic stations located in the major crop producing regions of each state or province (USDA, 2006) (Table 1). For states or provinces with more than one climate station, the data for the relevant stations have been equally weighed assuming that the stations represent equally sized cropproducing areas. The actual irrigation water use (FAO, 2007a) is taken equal to the irrigation requirements as estimated with the CROPWAT model for those countries where the whole harvesting area is reportedly irrigated (Chapagain et al., 2006b). In the countries where only a certain fraction of the harvesting area is irrigated, the actual irrigation water use is taken equal to this fraction times the irrigation water requirements (ibid.).

The 'green' virtual-water content of the crop has been estimated as the ratio of the green water use to the crop yield, where green water use is equal to the minimum of effective rainfall and crop water requirement (Chapagain et al., 2006b). The 'blue' virtual-water content of the crop has been taken equal to the ratio of the volume of irrigation water used to the crop yield (ibid.). Both green and blue virtual-water contents have been estimated separately by state or province. Then, national average green and blue virtual-water contents have been calculated on the basis of the respective share of each state or province to the national production (Chapagain et al., 2006b). The major crop producing states or provinces combined accounted for about 90 per cent of the total national production (Table 1). In the case of the USA, winter and spring wheat were separately 
calculated and weighted according to the share of each to the national production. The total virtual-water content of primary crops is the sum of the green and blue components.

\subsection{Virtual-water flows related to trade}

In order to assess the virtual-water flows between nations, the basic approach has been to multiply international trade volumes (ton/year) by their associated virtual-water content $\left(\mathrm{m}^{3} /\right.$ ton) for the 2000-2004 period. It is thus assumed that states or provinces within a country contribute to the national export in proportion to their total production.

\subsection{Data sources and shortcomings}

The estimates of the virtual-water contents of crops have a number of shortcomings due to a lack of available data. First, there are no climatic stations in every harvested region. Climate data of the producing country are taken from the CLIMWAT database (FAO, 2003b), which provides data restricted to a number of climatic stations. Second, in the case of USA winter wheat, cropping calendars do not fit the crop parameters available. Concerning crop parameters, crop coefficients for different crops are taken from FAO (Allen et al., 1998; FAO, 2003a) and crop lengths from the work of Chapagain and Hoekstra (2004). In the case of the USA, the planting dates and cropping calendar are taken from USDA (2007). According to USDA (2007), however, USA winter wheat has long crop periods that do not fit neither crop parameters per climatic region (Chapagain and Hoekstra, 2004) nor FAO parameters (Allen et al., 1998; FAO, 2003a). USA winter wheat crop lengths have been adjusted accordingly. Third, losses from irrigation systems are not available. Data on water withdrawals, taken from AQUASTAT database (FAO, 2007a), are thus assumed to be equal to the consumption. As for the rest of the data no problem was found. Data on average crop yield and production by state or province are taken from Statistics Canada (2007), USDA (2007), SAGPyA (2007) and USDA-FAS (2007), and data on international trade from the FAOSTAT database (FAO, 2007b). 


\section{Proportion of green water in international crop trade}

\subsection{Virtual-water content of maize, soybean and wheat in the major exporting countries}

Virtual-water flows are assessed on the basis of the virtual-water content of the products in the exporting countries. First of all, the results of the present study are analysed and compared with those obtained by Chapagain and Hoekstra (2004) (Table 1). No other analogous study was found in the literature. Table 1 summarises the virtual-water content $\left(\mathrm{m}^{3} / \mathrm{ton}\right)$ of maize, soybean and wheat for the USA, Canada, Argentina and Australia over the period 2000-2004 as estimated by the present study against the results of Chapagain and Hoekstra (2004) for the same countries and crops during 1997-2001. According to expectations, since both studies use the same methodology, similar outcomes have been obtained except for USA wheat. Its higher virtual-water content is probably due to the fact that the present research uses longer winter wheat growing periods according to USDA (2007).

The average virtual-water content of the crops in the selected countries gives a first rough indication of the relative impacts of the various production systems on water (Chapagain et al., 2006b). In this sense, local data on productivities can tell where water use per unit of product is relatively large and where small (Hoekstra, 2007). The water need per unit of product depends on both climate and water-use efficiency (ibid.) Apart from reducing water use through adjusting consumption patterns or using water more efficiently, the reduction of water use by producing where the climate is most suitable is one of the options in order to save water at a national or global level (Hoekstra, 2007; Hoekstra and Chapagain, 2008). The water use for crop production thus differs considerably among countries. In principle, and coinciding with the results of Chapagain and Hoekstra (2004), soybean and wheat production is most attractive in Argentina due to its higher water productivity (Table 1). That is, products are water-extensive because they require less water in their production and therefore have low virtual-water content. Maize from Argentina, soybeans from Canada and wheat from the USA are the most water-intensive. When comparing different crops, maize appears to be the most waterextensive in all the selected countries, in line with the results of Chapagain and Hoekstra (2004).

No comparable results were found for green and blue water content in the literature. Since green water generally has a lower opportunity cost than blue water, it is useful to look at the ratio of green to blue water content for the selected crops and countries (Table 1). In all the studied countries green water is by far the dominant use, displaying in all cases ratios larger that one. For maize, the largest ratio of green to blue water content is found in Canada, which thus has the lowest impact per unit of crop. This is probably due to the reasonable yields under largely rain-fed conditions. For soybean, Canada and Argentina have comparable green to blue water ratios, considerably higher than the USA. Concerning wheat production, Argentina has the highest ratio. When comparing neighbouring countries from a water resources perspective, all the studied crops from Canada are preferable over those from the USA due to better growing conditions (smaller irrigation requirements). Although Canada achieves lower crop yields per hectare than the USA, its blue water requirements per ton of product are lower (Table 1). 


\begin{tabular}{|c|c|c|c|c|c|c|c|c|}
\hline \multirow{5}{*}{\multicolumn{2}{|c|}{ ह }} & 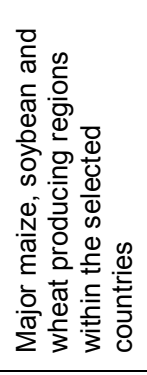 & 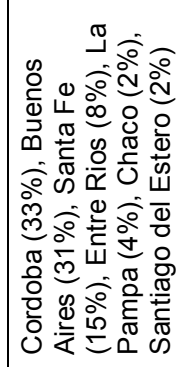 & 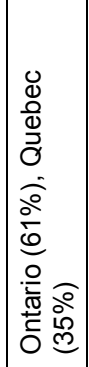 & 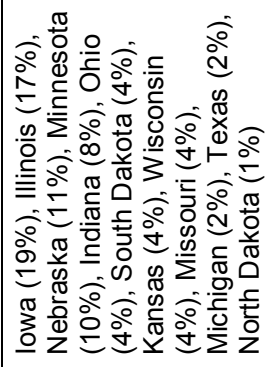 & 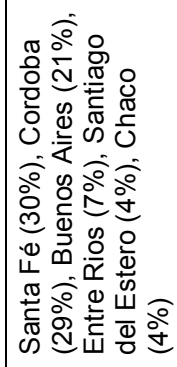 & 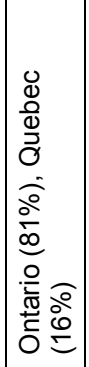 & 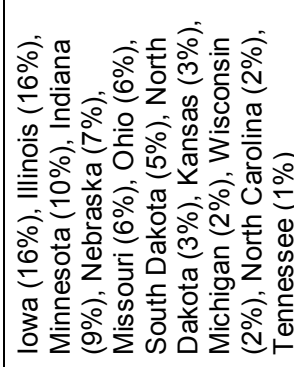 \\
\hline & & 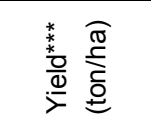 & 令 & $\underset{N}{N}$ & $\begin{array}{l}\infty \\
\infty \\
\infty \\
\infty\end{array}$ & $\stackrel{5}{\text { N }}$ & $\stackrel{\text { N }}{\text { }}$ & $\stackrel{\infty}{\stackrel{\infty}{N}}$ \\
\hline & & 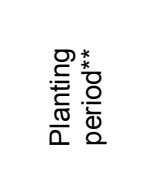 &  & 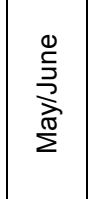 & 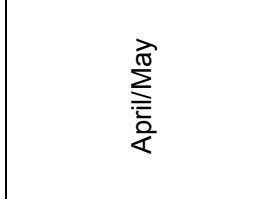 & 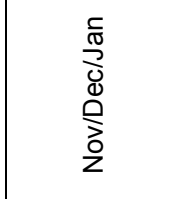 &  & 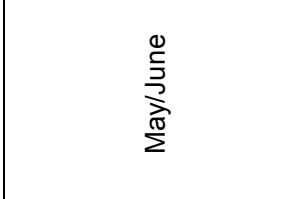 \\
\hline & & 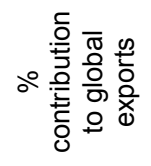 & $\stackrel{\widehat{N}}{\stackrel{\mathrm{I}}{ }}$ & @़ & $\begin{array}{l}\circ \\
\stackrel{\leftrightarrow}{\circ}\end{array}$ & $\stackrel{r}{F}$ & 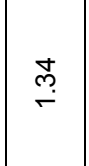 & $\begin{array}{l}\infty \\
\stackrel{\infty}{q}\end{array}$ \\
\hline & & 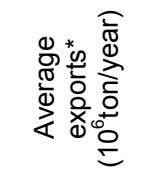 & $\begin{array}{l}\stackrel{0}{2} \\
\stackrel{0}{\circ}\end{array}$ & 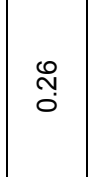 & 齐 & 冓 & $\stackrel{\stackrel{R}{2}}{\stackrel{0}{0}}$ & $\begin{array}{l}\infty \\
\infty \\
\text { N }\end{array}$ \\
\hline 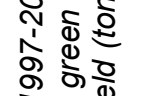 & \multirow{3}{*}{ 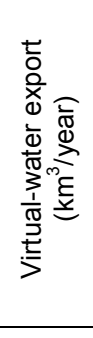 } & 要 & $\underset{0}{\tilde{\theta}}$ & $\stackrel{\sim}{\circ}$ & $\stackrel{\circ}{\text { N }}$ & $\begin{array}{l}\circ \\
\infty \\
\infty\end{array}$ & 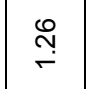 & 迥 \\
\hline$\frac{0}{0}$ & & 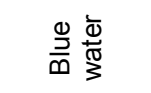 & $\begin{array}{l}\infty \\
\infty \\
0\end{array}$ & : & $\underset{+}{\stackrel{8}{+}}$ & $\stackrel{\mathbb{N}}{0}$ & Oั. & $\stackrel{8}{0}$ \\
\hline ర్రి & & 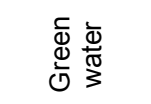 & مُ & $\stackrel{N}{\check{0}}$ & $\stackrel{m}{\stackrel{n}{\sim}}$ & ণิ & $\stackrel{\stackrel{্}{\longrightarrow}}{\sim}$ &  \\
\hline 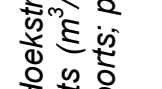 & \multirow{5}{*}{ 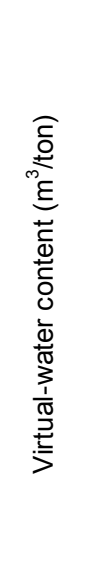 } & \multirow{4}{*}{ 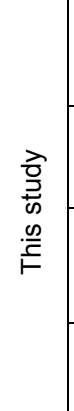 } & $\overleftrightarrow{0}$ & $\begin{array}{l}0 \\
\qquad 0 \\
\stackrel{0}{\circ}\end{array}$ & $\hat{m}$ & $\begin{array}{l}n \\
0 \\
0\end{array}$ & $\begin{array}{l}\infty \\
\infty \\
\infty \\
i \infty\end{array}$ & $\stackrel{9}{+}$ \\
\hline 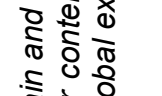 & & & ঃ & ナ & 8 & $\stackrel{\sim}{N}$ & $\stackrel{\infty}{\sim}$ & 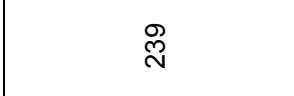 \\
\hline 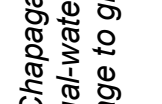 & & & $\frac{20}{5}$ & $\stackrel{P}{f}$ & o্ & $\stackrel{\infty}{\stackrel{\infty}{N}}$ & @ & 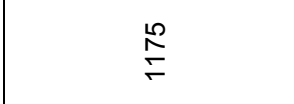 \\
\hline 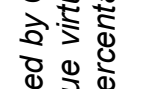 & & & 吕 & $\stackrel{+}{\mathscr{\sigma}}$ & \& & $\stackrel{\bar{్}}{\sim}$ & $\begin{array}{l}\infty \\
\stackrel{\leftrightarrow}{\circ}\end{array}$ & $\stackrel{m}{g}$ \\
\hline 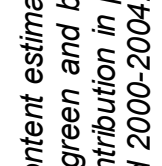 & & 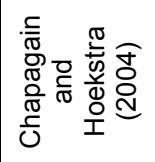 & $\stackrel{8}{q}$ & 足 & $\stackrel{\mathscr{\infty}}{\stackrel{\infty}{\sigma}}$ & $\stackrel{ }{\circ}$ & 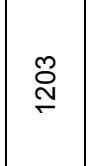 & $\stackrel{\stackrel{̊}{\circ}}{\stackrel{\infty}{\leftarrow}}$ \\
\hline 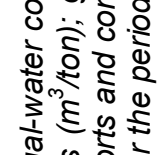 & & $\begin{array}{l}\text { 辛 } \\
\text { Oे } \\
\text { O }\end{array}$ & 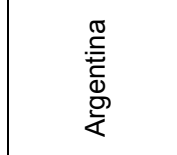 & $\begin{array}{l}\frac{\pi}{0} \\
\frac{\pi}{\pi} \\
\frac{\pi}{\pi} \\
0\end{array}$ & 兵 & 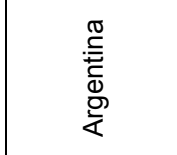 & $\begin{array}{l}\frac{\pi}{0} \\
\frac{\pi}{\pi} \\
\frac{\pi}{\pi} \\
0\end{array}$ & 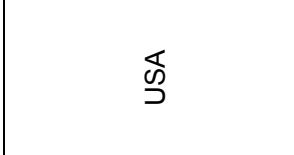 \\
\hline 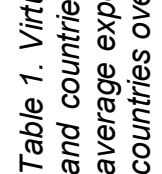 & & 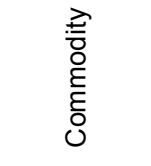 & \multicolumn{3}{|c|}{$\stackrel{\stackrel{D}{N}}{\stackrel{N}{\tilde{N}}}$} & \multicolumn{3}{|r|}{ 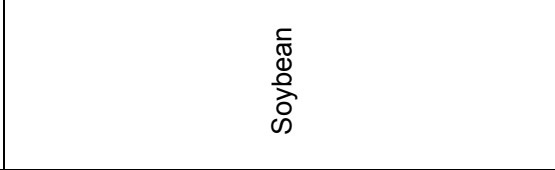 } \\
\hline
\end{tabular}




\begin{tabular}{|c|c|c|c|c|c|c|c|}
\hline & \multicolumn{2}{|c|}{ 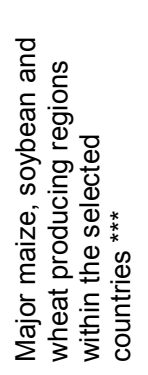 } & 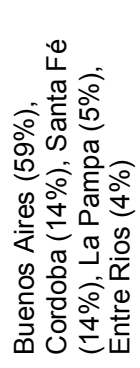 & 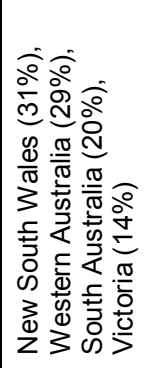 & 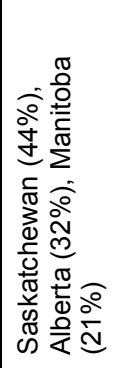 & 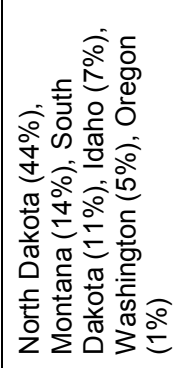 & 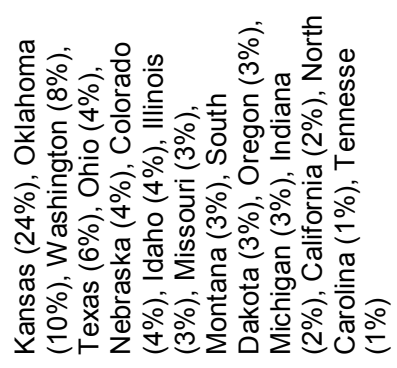 \\
\hline & \multicolumn{2}{|c|}{ 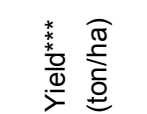 } & $\stackrel{\widehat{m}}{\stackrel{N}{N}}$ & $\stackrel{?}{r}$ & $\underset{N}{N}$ & \multicolumn{2}{|r|}{$\stackrel{\stackrel{R}{\sim}}{\stackrel{N}{N}}$} \\
\hline & \multicolumn{2}{|c|}{  } & 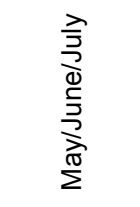 &  & $\sum^{\frac{\pi}{2}}$ & 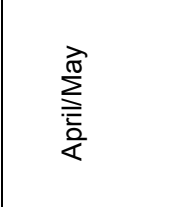 & $\begin{array}{l}\overrightarrow{0} \\
\stackrel{0}{0} \\
\overline{0} \\
\dot{\omega}\end{array}$ \\
\hline & \multicolumn{2}{|c|}{ 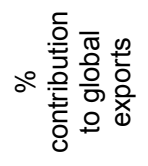 } & $\underset{\infty}{\stackrel{d}{d}}$ & $\stackrel{m}{\stackrel{m}{ }}$ & 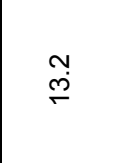 & \multicolumn{2}{|r|}{$\stackrel{0}{\stackrel{\sim}{j}}$} \\
\hline & \multicolumn{2}{|c|}{  } & $\begin{array}{l}\text { of } \\
\sigma\end{array}$ & 文 & $\begin{array}{l}\stackrel{8}{\circ} \\
\stackrel{\circ}{\circ}\end{array}$ & \multicolumn{2}{|r|}{ 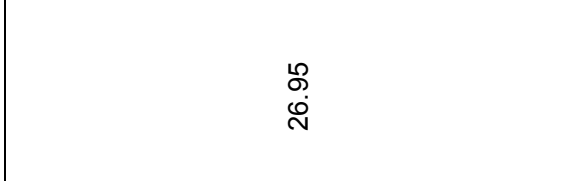 } \\
\hline \multirow{3}{*}{ 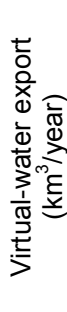 } & \multicolumn{2}{|c|}{$\begin{array}{l}\bar{\pi} \\
\text { 임 }\end{array}$} & $\underset{\substack{\sim \\
0}}{\stackrel{0}{0}}$ & $\stackrel{\infty}{\stackrel{N}{N}}$ & $\stackrel{\circ}{\circ}$ & \multicolumn{2}{|r|}{$\stackrel{\circ}{\dot{g}}$} \\
\hline & \multicolumn{2}{|c|}{ 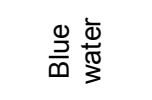 } & I্ & $\frac{10}{6}$ & $\stackrel{\text { }}{\leftarrow}$ & \multicolumn{2}{|r|}{$\stackrel{\substack{\infty \\
\infty}}{\infty}$} \\
\hline & \multicolumn{2}{|c|}{ 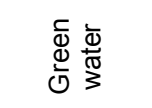 } & ڤึ & $\hat{\varphi}$ & 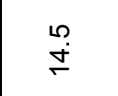 & \multicolumn{2}{|r|}{$\hat{i}$} \\
\hline \multirow{5}{*}{ 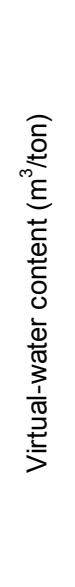 } & \multirow{4}{*}{ 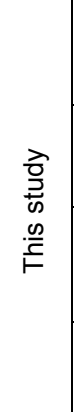 } &  & $\begin{array}{l}\infty \\
\stackrel{\infty}{\sim}\end{array}$ & $\hat{\mathrm{i}}$ & $\stackrel{\text { Nִ }}{\circ}$ & \multicolumn{2}{|r|}{$\stackrel{n}{\sim}$} \\
\hline & & $\frac{\Phi}{\underline{m}}$ & $\stackrel{\sim}{N}$ & $\stackrel{\text { P̊ }}{q}$ & ஜ & \multicolumn{2}{|r|}{$\stackrel{\mathscr{Q}}{\hat{0}}$} \\
\hline & &  & ஜ) & 흥 & ஜ & \multicolumn{2}{|r|}{$\stackrel{\stackrel{\sim}{N}}{\stackrel{0}{\sigma}}$} \\
\hline & & 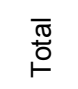 & $\stackrel{\stackrel{N}{N}}{\sim}$ & 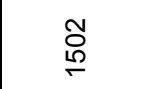 & ஸे & \multicolumn{2}{|r|}{$\stackrel{ }{\stackrel{2}{ }}$} \\
\hline & \multicolumn{2}{|c|}{ 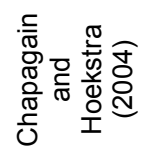 } & $\stackrel{\infty}{\sim}$ & $\begin{array}{l}\infty \\
\stackrel{\circ}{\circ} \\
\stackrel{\circ}{\sim}\end{array}$ & 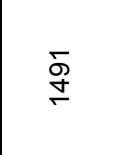 & \multicolumn{2}{|r|}{$\underset{\infty}{\stackrel{9}{\infty}}$} \\
\hline & \multicolumn{2}{|c|}{ 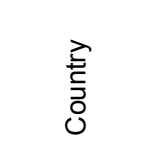 } & 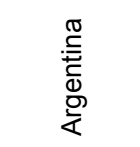 & 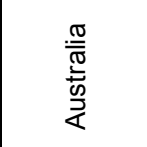 & 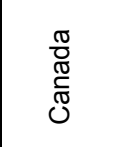 & \multicolumn{2}{|r|}{ 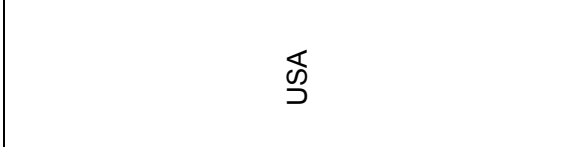 } \\
\hline & \multicolumn{2}{|c|}{  } & \multicolumn{3}{|c|}{ 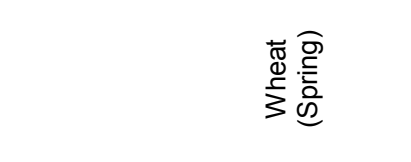 } & \multicolumn{2}{|r|}{  } \\
\hline
\end{tabular}

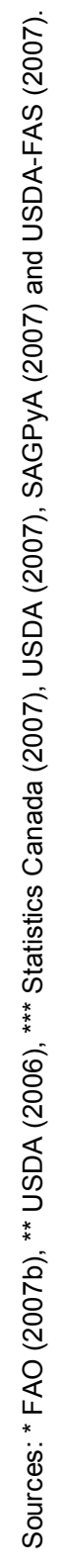




\subsection{Water use for export in the major exporting countries}

The nations with the largest water loss in relation to maize, soybean and wheat exports during the period 20002004 are the USA (108 $\mathrm{km}^{3} /$ year), Argentina (23 km 3 year), Australia (just accounting for wheat $-23 \mathrm{~km}^{3} /$ year) and Canada (17 km³/year) (Table 1). Following Chapagain et al. (2006a) the term 'national water loss' refers to the fact that water used for producing commodities consumed by people in other countries is not available anymore for domestic purposes. Export of agricultural products entails that national water resources are lost whereas import of agricultural products saves national water resources (Chapagain et al., 2006a). The terms 'loss' is not to be interpreted in terms of economic loss, but in a physical manner (ibid.). National water losses may be positive or negative from an economic perspective depending on the context. In line with Chapagain et al. (2006a) water losses are positive in economic sense if the benefit in terms of foreign earnings they provide is outweighed by the opportunity costs of water use and the negative externalities left at the production site. Even if there is a net global water loss from an exchange, there might be a saving of blue water at the cost of a greater loss of green water or vice versa (ibid.).

Figure 1 shows the proportion of green and blue virtual-water losses by crop and country. Noticeably, virtualwater exports are overwhelmingly "green" in all the studied countries and crops. This indicates that crop production in the selected countries is dominantly rain-fed and that it is mostly green water that is exported. On the whole, these green water losses can be positively evaluated in economic terms since they are efficient in terms of opportunity costs of water use and reasonably efficient with regard to negative externalities (Yang et al., 2006). Unlike blue water, green water cannot be automatically reallocated to other uses besides natural vegetation or alternative rain-fed crops (De Fraiture et al., 2004). Since blue water resources are generally scarcer, when exporting countries use green water resources they incur a lower opportunity cost in water use, holding other factors constant (Chapagain et al., 2006a). In terms of water resource use, trading "green virtual water" is more efficient than "blue virtual water", keeping other conditions constant (Yang et al., 2006). Concerning the potential negative externalities in these rain-fed countries, they are relatively small even if there is an increased risk of loss of natural environments (Rosegrant et al., 2002; De Fraiture et al., 2004).

In the cases of Canada and Argentina, the proportion of the blue virtual-water exports is relatively small (Figure 1). Wheat exports constitute the main source of water loss for Canada, which is almost entirely rain-fed since it can be grown in cool seasons, with low water requirements (Chapagain et al., 2006a). The national water loss for Argentina is mainly the result of soybean exports, which is also almost entirely rain-fed. In the case of Australia, almost one third of total wheat exports are blue water resources (surface and ground water). The USA accounts for more than three quarters of all studied water losses related to maize and soybean exports and over a half of the water loss related to wheat export, making the country by far the biggest water user for export. Even if USA's food production is dominated by rain-fed agriculture, in recent years irrigation has seen a significant increase (FAO, 2007a). This case thus deserves particular attention. 

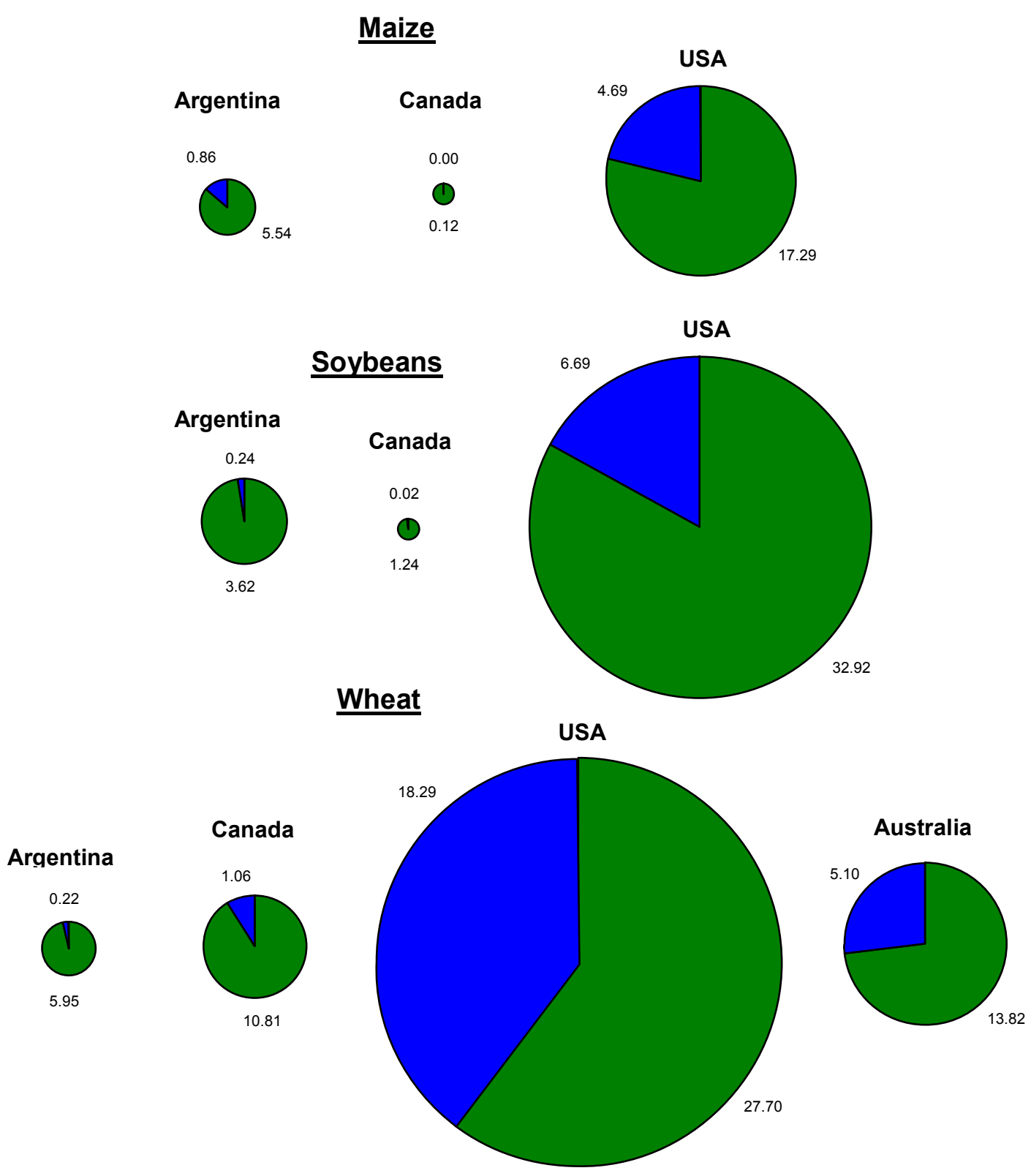

Figure 1. Green and blue water proportion in the virtual-water embedded in the maize, soybean and wheat exports of main exporting countries ( $\left.\mathrm{km}^{3} / \mathrm{year}\right)$. The size of the pie is determined by the exported amount of virtual water. Period 2000-2004.

\section{The USA}

As mentioned before, the USA like the rest of the largest exporting countries, is mainly based on green water resources. Maize and soybeans are grown without irrigation due to the exceptionally favourable agroclimatic conditions of the "corn belt" (Seckler et al., 2000) and exported in large quantities. The "corn belt" refers to the Midwest of the USA, primarily including the States of Iowa, Indiana, Illinois, and Ohio, where maize and soybeans are the predominant crop (Encyclopaedia Britannica, 2007). In this region, both maize and soybeans present a large green to blue water use ratio (Figs. 2 and 3). The use of green water has no major competition with other uses. This type of loss of the national water resources is unlikely to be questionable from an economic perspective, due to its low opportunity cost (Chapagain et al., 2006a). 


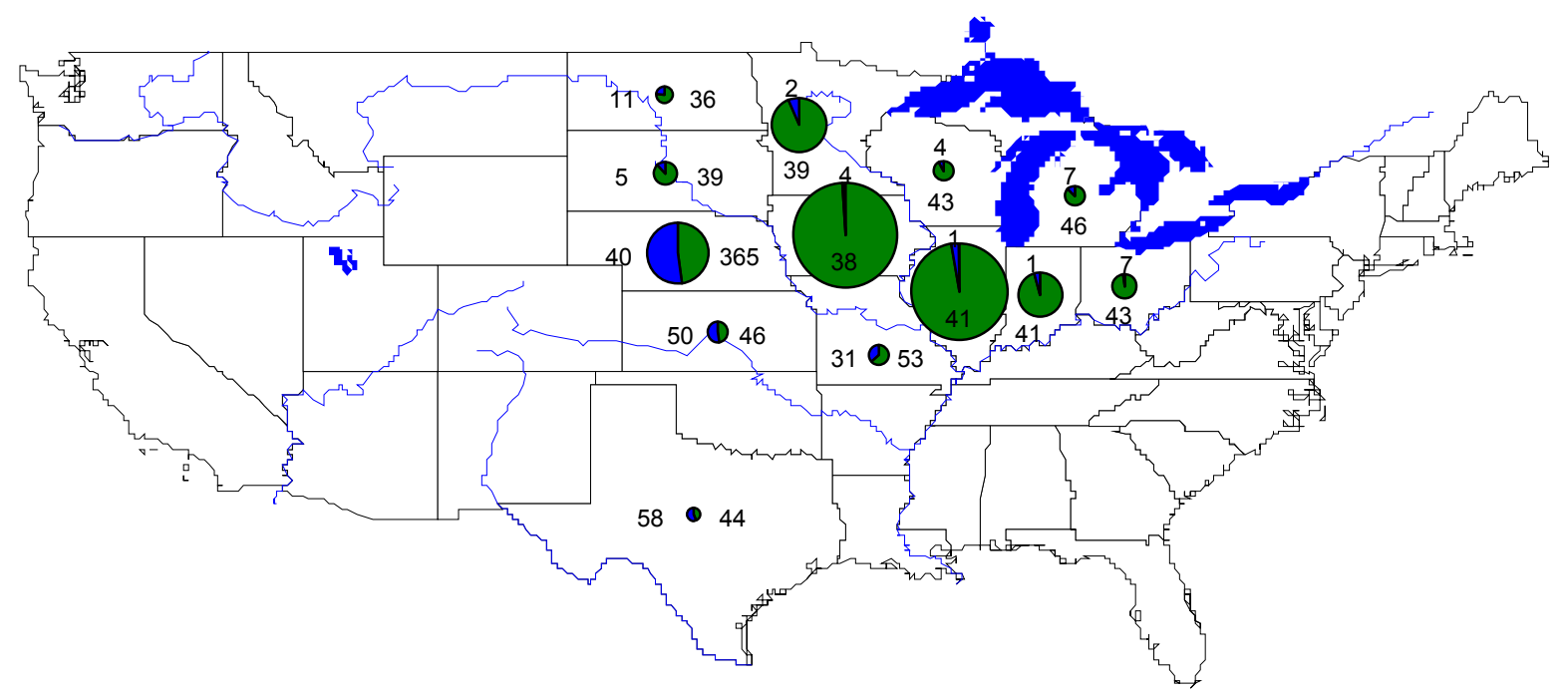

Figure 2. Green and blue water resource use for the USA maize production by state $\left(\mathrm{m}^{3} /\right.$ ton). The size of each pie reflects the state contribution to the national production.

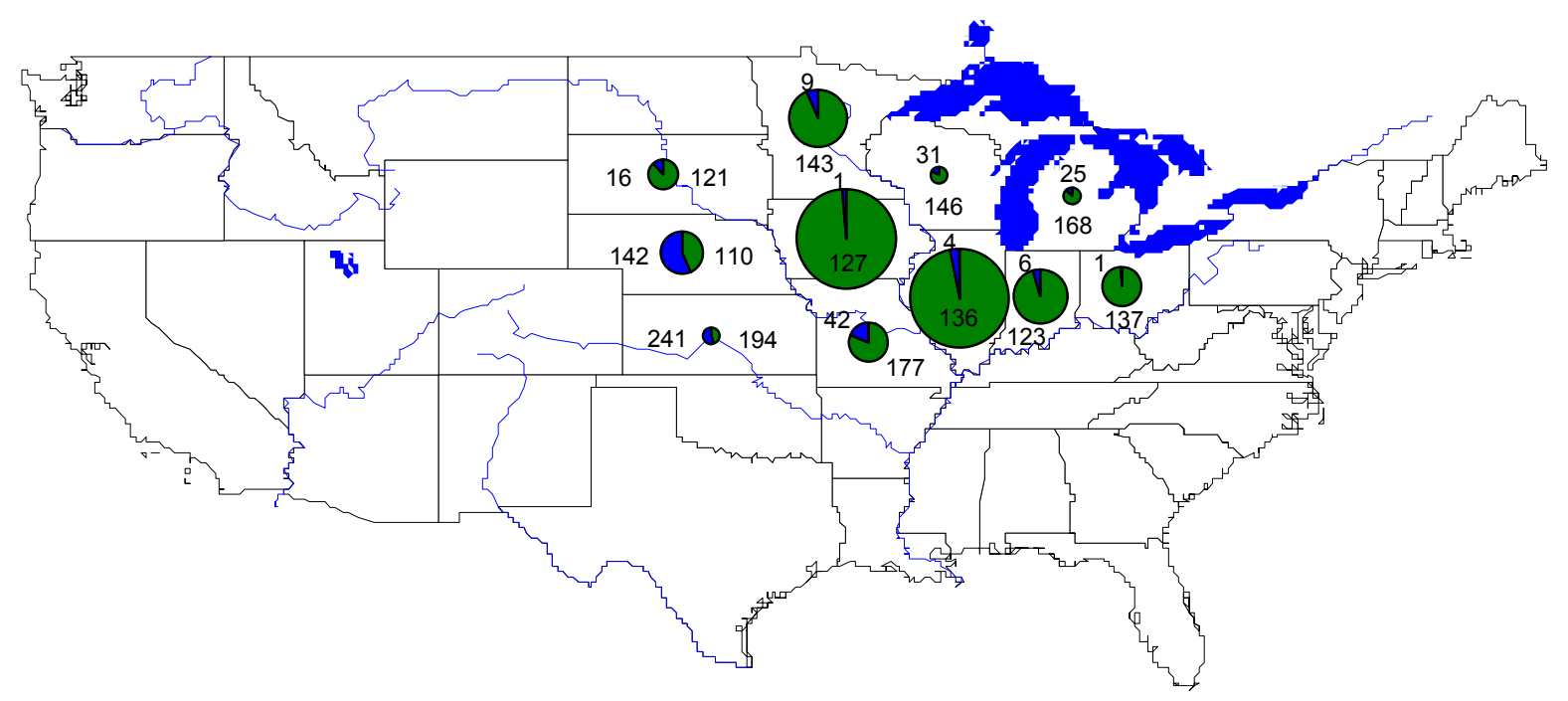

Figure 3. Green and blue water resource use for the USA soybean production by state $\left(\mathrm{m}^{3} /\right.$ ton). The size of each pie reflects the state contribution to the national production.

Although crop production in the USA is mainly rain-fed, irrigation has notably increased in recent years (FAO, 2007a). Nowadays, irrigated agriculture is a major user of ground and surface water in the USA, accounting for 80 per cent of the nation's consumptive water use and over 90 per cent in many Western States (USDA/ERS, 2007). Overexploitation of water resources has occurred in many regions. In the central and western part of the country many open-access common-pool resources such as rivers and aquifers have been over-exploited causing water resource depletion and environmental degradation (Figs. 4 and 5) (Ostrom, 1990). For instance, the heavy use of the Colorado river as an irrigation source for the Imperial Valley (region of South-eastern California) has desiccated the lower course of the river in Mexico. Another example is the groundwater pumping in excess of recharge, which has caused significant groundwater depletion in the Western United States (Rosegrant et al., 
2002), such as the mining of the Ogallala Aquifer ${ }^{1}$. Groundwater overdraft can lead to significant problems in both water quality and water availability; thus, excessive groundwater use is a critical policy issue in balancing water uses for food production and the environment (Rosegrant et al., 2002).

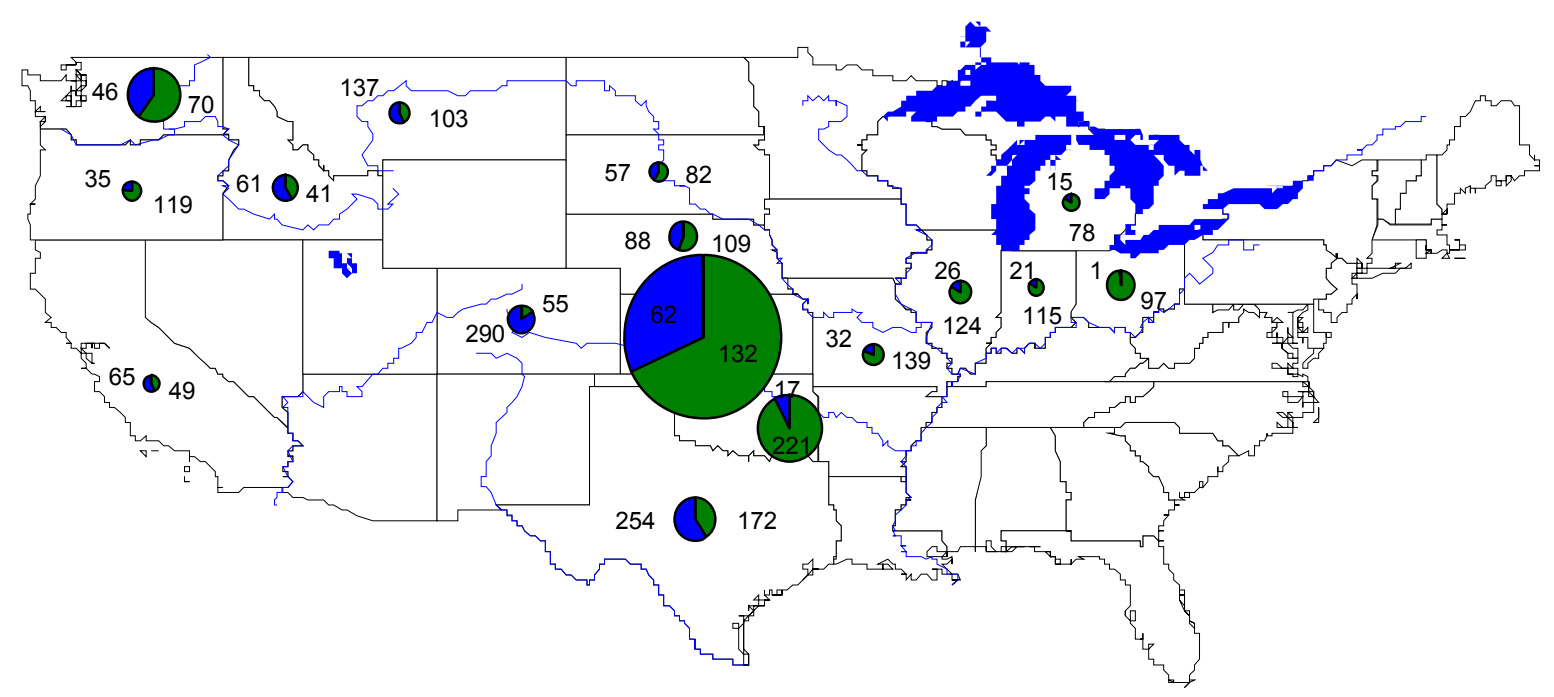

Figure 4. Green and blue water resource use for the USA winter wheat production by state ( $\mathrm{m}^{3} /$ ton). The size of each pie reflects the state contribution to the national production.

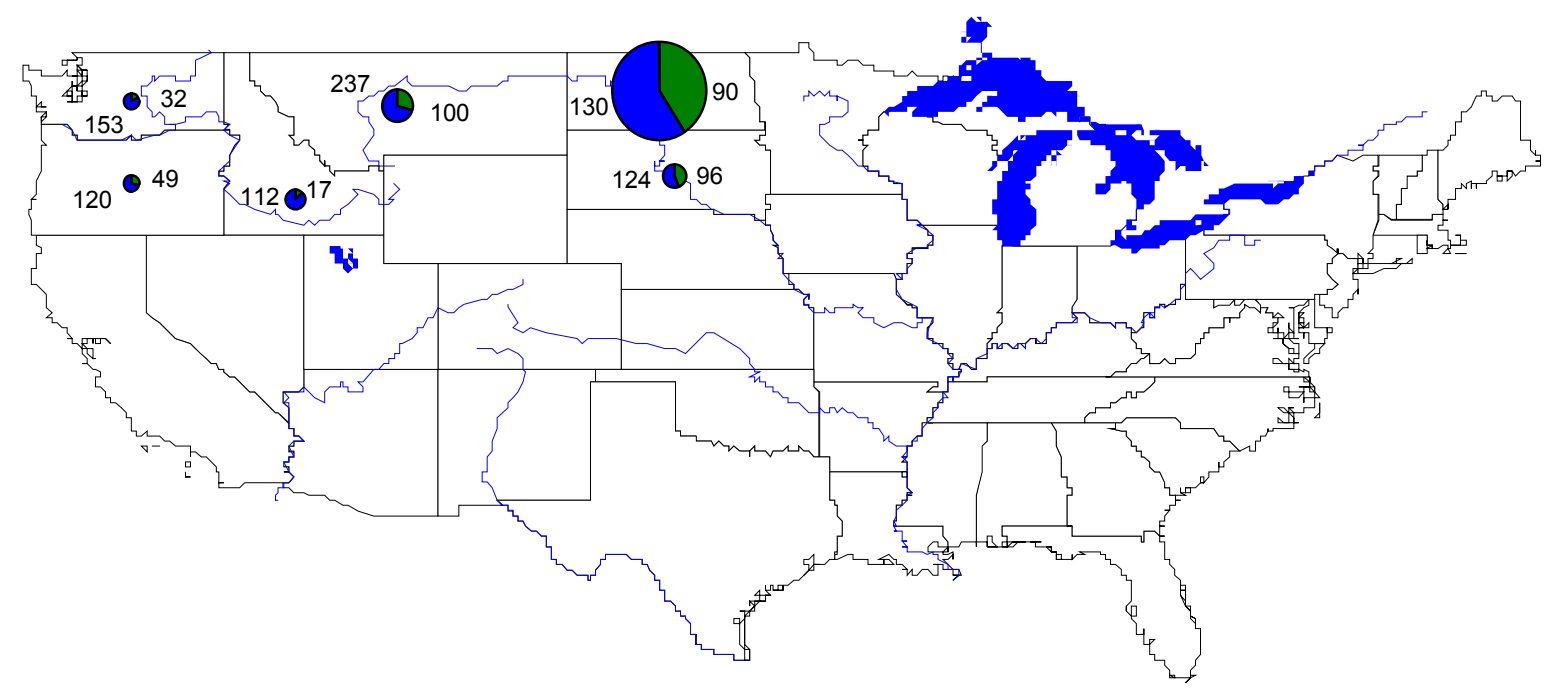

Figure 5. Green and blue water resource use for the USA spring wheat production by state $\left(\mathrm{m}^{3} /\right.$ ton). The size of each pie reflects the state contribution to the national production.

\footnotetext{
${ }^{1}$ The Ogallala Aquifer is one of the world's largest aquifers, lying under about $450,000 \mathrm{~km}^{2}$ in portions of the eight states of South Dakota, Nebraska, Wyoming, Colorado, Kansas, Oklahoma, New Mexico, and Texas. The regions overlying the Ogallala aquifer are some of the most productive regions for growing corn, wheat and soybeans in the United States (often called the "breadbasket of America"). Some areas do not have adequate precipitation and do not always have perennial surface water for diversion, therefore, depending on pumping groundwater for irrigation. Today, water is being extracted at rates exceeding by far the natural replacement rate.
} 
The negative externalities of water use, such as water depletion, are generally neither internalized into the price of water nor translated into the price of products, with sometimes an exception for the costs made for wastewater treatment (Hoekstra, 1998; Chapagain et al., 2006a). The USA partially utilizes treated recycled sources of water for agriculture in order to reduce the amount of water use (USDA/ERS, 2007). Given the general lack of proper water pricing mechanisms or other ways of transmitting production-information, consumers have little incentive to take responsibility for the impacts on remote water systems (Chapagain et al., 2006b).

This "Tragedy of the Commons" (Hardin, 1968) can be overcome by strengthened private or public property rights. Water prices are a powerful tool for influencing water demand in domestic, industrial, and agricultural sectors, and therefore in determining the availability of water for the environment (Rosegrant et al., 2002). Policies including water pricing or allocation programs, reflect scarcity conditions and encourage users to consider those values reaching the optimum level of water use (Seckler et al., 2000; Rosegrant et al., 2002; CAWMA, 2007). Since societal water needs and aquatic ecosystems are blue-water dependent whereas land use and terrestrial ecosystems are green-water dependent, and changes in land use affect green water flows and determine the available blue water flows further downstream, it is essential to address the land/water linkages (Falkenmark, 2003; Falkenmark and Rockström, 2004). Freshwater management has to be integrated with the management of ecosystem dynamics. This is equivalent to finding ways and means to merge water management, land-use management and ecosystem management (terrestrial as well as aquatic) within a socio-ecohydrological catchment management (Falkenmark, 2003).

\subsection{Water saving in the importing countries}

Importing countries are more diverse than exporting countries: 37 countries account for 90 per cent of maize imports, 22 of soybean and 55 of wheat. The top-10 importing countries include Japan, China, Korea, Egypt, Netherlands, Spain and Mexico. The maps presented in Figures 6 to 8 show the virtual-water flows to the five major importing countries for the studied crops for the period 2000-2004. The figures show the composition of the virtual-water flows in terms of blue and green shares.

By importing virtual water embodied in agricultural commodities, a nation "saves" the amount of water it would have required to produce those commodities domestically. This is relevant since in importing countries the opportunity cost of blue or irrigation water is generally high. Moreover, excessive irrigation can cause severe environmental problems such as water depletion, salinisation, water logging or soil degradation. Though from an importing country perspective it is not relevant whether products have been produced using green or blue water in the country of origin, from a global point of view it has important implications (Chapagain et al., 2006a). This will be considered here in the case of Egypt's national water saving in relation to wheat import. 

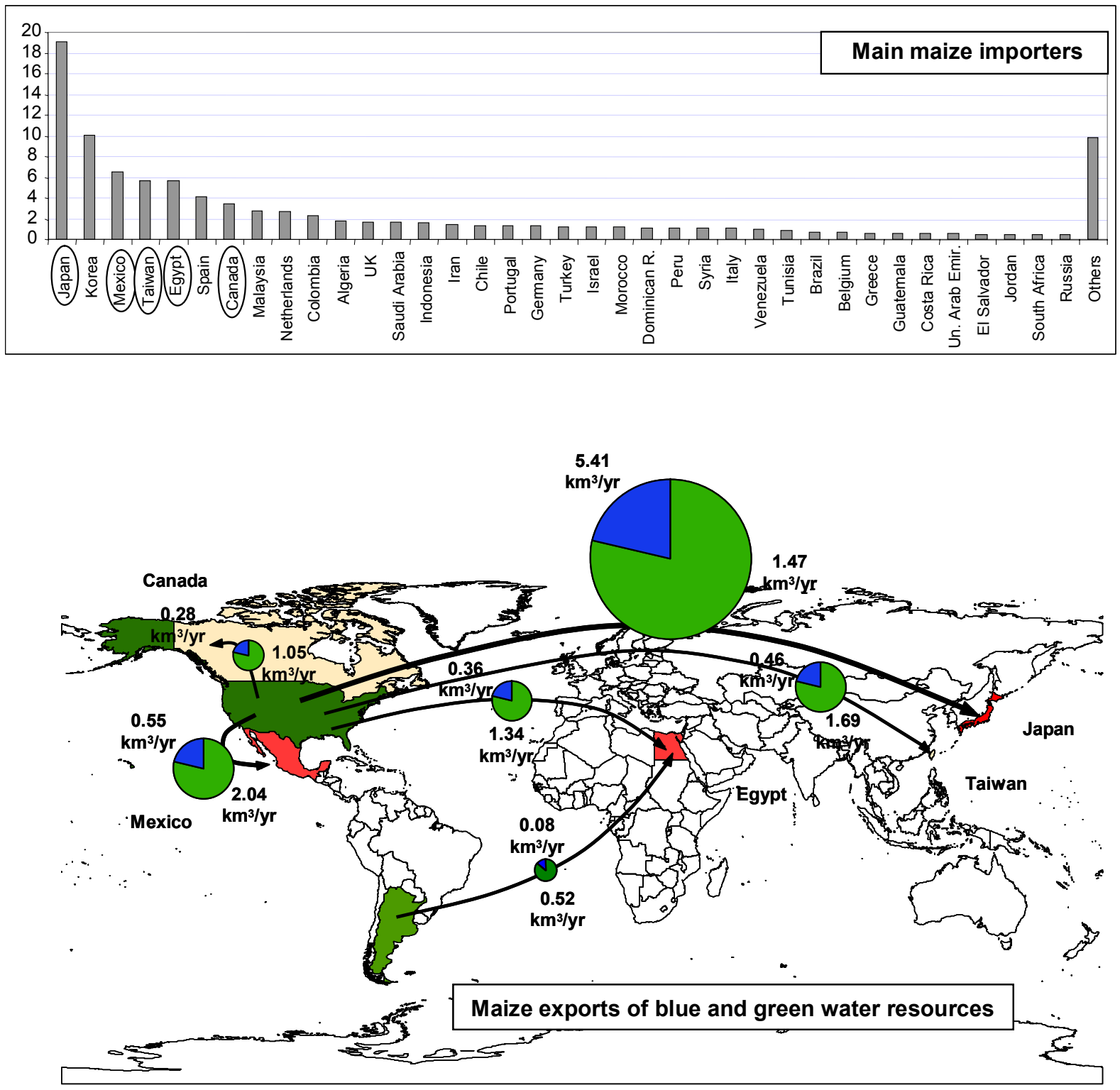

Figure 6. Green and blue virtual-water flows related to maize trade by major exporting and importing nations $\left(\mathrm{km}^{3} /\right.$ year). The size of each pie is determined by the amount of virtual water traded. Countries with virtual-water exports are depicted in green and countries with virtual-water import in red; the colour shade depends on the quantity of virtual water traded. Period 2000-2004. 

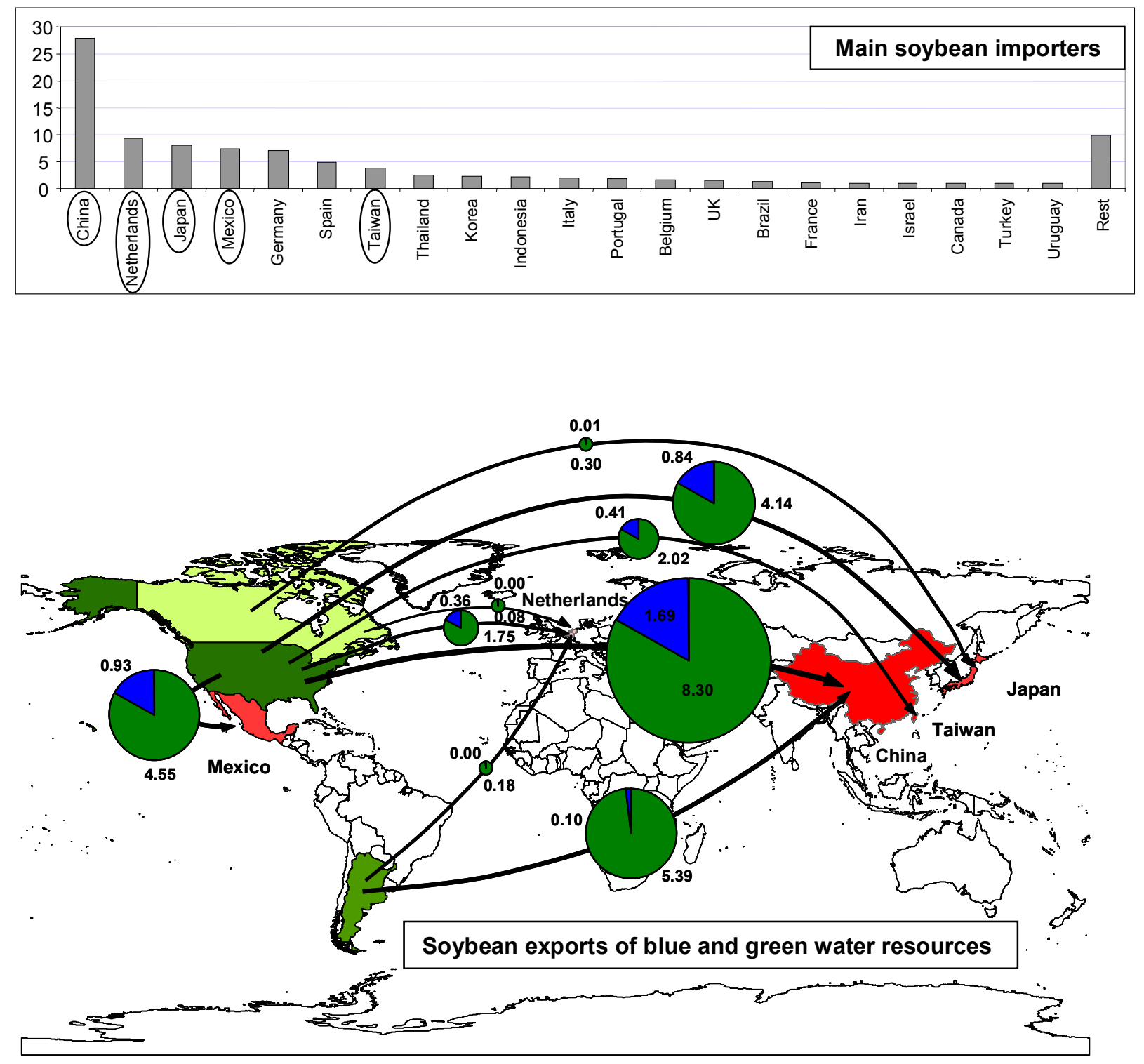

Figure 7. Green and blue virtual-water flows related to soybean trade by major exporting and importing nations ( $\mathrm{km}^{3} /$ year). The size of each pie is determined by the amount of virtual water traded. Countries with virtual-water exports are depicted in green and countries with virtual-water import in red; the colour shade depends on the quantity of virtual water traded. Period 2000-2004. 

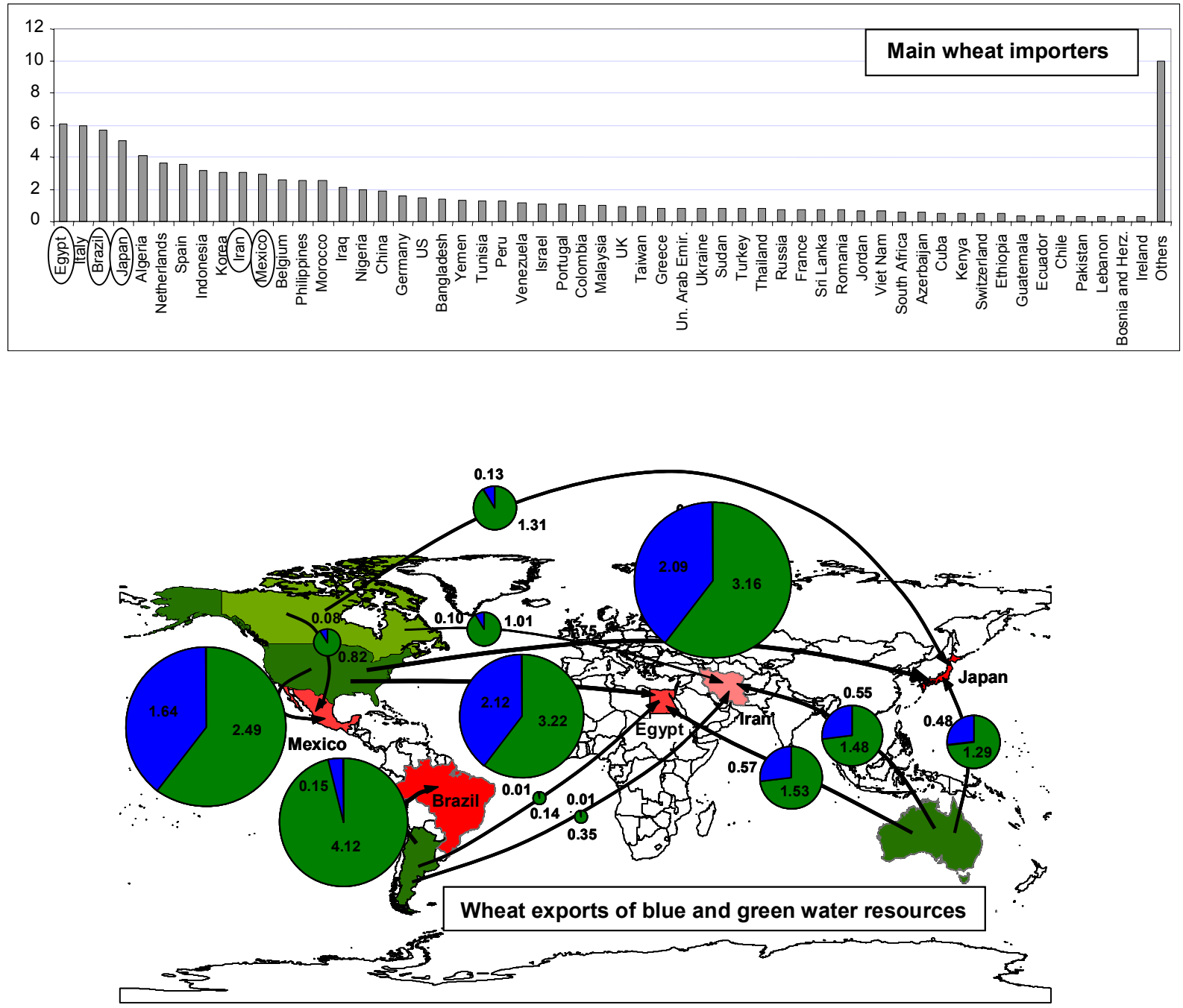

Figure 8. Green and blue virtual-water flows related to wheat trade by major exporting and importing nations $\left(\mathrm{km}^{3} /\right.$ year). The size of each pie is determined by the amount of virtual water traded. Countries with virtual-water exports are depicted in green and countries with virtual-water import in red; the colour shade depends on the quantity of virtual water traded. Period 2000-2004. 


\section{Egyptian wheat imports}

Egypt is the largest importer of wheat, with the USA and Australia providing about 45 and 20 per cent of the country's imports, respectively (Fig. 8). Wheat from Egypt has an average virtual-water content of $930 \mathrm{~m}^{3} /$ ton (Chapagain et al., 2006a), while the USA and Australia display virtual-water contents for wheat of 1707 and $1502 \mathrm{~m}^{3} /$ ton, respectively (Table 1). Exports to Egypt from these two countries result in a considerable net global water loss (777 and $572 \mathrm{~m}^{3}$ per ton, respectively). With a mean rainfall of $18 \mathrm{~mm} /$ year and an almost fully irrigated agriculture (annual supply from Lake Nasser is about $55.6 \mathrm{~km}^{3}$ ), all water used for wheat in Egypt is considered blue water, and the green component is considered to be zero (CAWMA, 2007). Accordingly, wheat imports to Egypt result in exclusively green water losses of $777 \mathrm{~m}^{3}$ per ton traded from USA and 572 from Australia. While all the water savings for Egypt are blue: $251 \mathrm{~m}^{3}$ of water per ton imported from USA and 525 from Australia. Wheat import into Egypt is therefore saving scarce blue water resources and making use of effective rainfall (green water) in the partner countries. The net global water loss related to the wheat export from the USA and Australia to Egypt results from the fact that the volume of blue water resources that would have been required in Egypt to produce domestically is replaced by a larger volume of green water resources actually used in these countries. Blue and green water resources fundamentally differ in terms of possible application and thus opportunity cost (Chapagain et al., 2006a). In this context, the import of wheat in Egypt is contributing to national water saving, specifically blue water saving. From an economic point of view, the opportunity cost of the water resources being saved should be more or at least equal to the price paid for it (ibid.). The import of wheat in Egypt still should be assessed including other factors of production such as land and labour (ibid.). Greenaway et al. (1994) and Wichelns (2001) have shown that the production of wheat has a comparative disadvantage in Egypt. As the saving is exclusively in blue water, the marginal utility of the saved water may justify the import. Along these lines, Egypt, as some other water-scarce importing countries, has formulated policies to import low value but high water consuming food like cereals (Van Hofwegen, 2005).

Even if it increases the dependency on other nations, virtual-water imports could be used by governments as a tool to release the pressure on their domestic water resources (Chapagain and Hoekstra, 2004). Virtual-water 'trade' between or within nations could also be seen as an alternative to inter-basin water transfers (Ma et al., 2006). This is for instance very relevant for China, where major real water transfer schemes (from the south to the north of China) are being considered (ibid.). Application of the idea of virtual-water 'trade' could have a positive impact on the management practice of international river basins as well (Nakayama, 2003).

Even if the potential of trade to "save" water at national level is substantial, most international food trade occurs for reasons not related to water resources (CAWMA, 2007). International trade in agricultural commodities mainly depends on factors such as availability of land, labour, technology, the costs of engaging in trade, national food policies and international trade agreements (Hoekstra and Hung, 2005). For example, a highly water-stressed country like Egypt saves water through grain imports from the United States (CAWMA, 2007). Mexico also saves water by importing wheat and maize from the USA (Chapagain and Hoekstra, 2004), though the main driver of this imports is more likely to be NAFTA than a desire to save Mexican water resources (Foreign Affairs and International Trade Canada, 2007). Japan is the world's biggest grain importer and a landscarce country (Oki and Kanae, 2004). China is the main soybean importer (Fig. 7) with a total use of domestic 
water resources composed of 59 per cent green and 41 per cent blue water (Hoekstra and Chapagain, 2008). For all these countries (Figs. 6 to 8), trade seems to make sense from both a water resources and an economic point of view. However, even if there is no net water loss, importing maize from USA to Canada generates a loss of blue water since crop conditions are more favourable in the latter. Reasons other than an optimal use of water resources, such as NAFTA or lower transportation costs, may explain these trade flows (Foreign Affairs and International Trade Canada, 2007).

A complicating factor with respect to rural economies and the use of water, mainly green water, is the USA and EU support to their agricultural sectors. This support adversely affects the rural economies of other countries, especially poor countries vulnerable to fluctuations in world market prices (Allan, 2001). Farmers in these countries cannot compete with subsidised commodities that depress local prices and reduce domestic production (Rosegrant et al., 2002). The current global virtual-water 'trade' is primarily among the countries above the lowincome level in the World Bank country classification. Countries with low-income levels are minor participants (Yang et al., 2006). As Allan (2006) points out, socio-economic development is a prerequisite to access virtual water in the global system. Some poor countries, such as Sub-Saharan Africa have yet to "take off" as Asia and Latin America did earlier (CAWMA, 2007). Finally, the two major factors contributing to increased food demand and to increased water use for food production, are population growth and changes in diets, shifting consumption patterns towards water-intensive livestock products, fish and high-value crops, as living standards improve (Hoekstra, 2003). The use of cereals and oilseeds for biofuel production can also contribute to an increase in the overall demand for agricultural commodities and to pressures on water resources (De Fraiture et al., 2007; Gerbens-Leenes et al., 2008).

\subsection{Global water saving}

Few are the studies that focus on virtual-water volumes at a global level. Those that do conclude that global trade in agricultural commodities saves water as a whole (Oki and Kanae, 2004; De Fraiture et al., 2004; Chapagain et al., 2006a; Yang et al., 2006). Very little, however, has been said about the opportunity cost of the associated water. Some trade flows may be more optimal than others because of the higher opportunity cost of the water being saved (Chapagain et al., 2006a). Chapagain and Hoekstra (2004) broadly estimated that nearly 67 per cent of the water used for crop production worldwide is green water, which has a lower opportunity cost compared to blue water use. This estimate is akin to the two thirds estimated by Rockström et al. (1999) and the 66 per cent in cereal production calculated by De Fraiture et al. (2004). In line with these studies, the present research shows that green water largely dominates the virtual water embodied in maize, soybean and wheat exports from major exporting countries, amounting to about 77 per cent of the total flow. When looking at each commodity individually, 81 per cent of maize, 86 per cent of soybean and 70 per cent of wheat exports represent green water. Thus, by adding estimates for three different commodities, this study complements the work of Chapagain et al. (2006b) for cotton. Their study concluded that international virtual water embedded in cotton products, mainly grown in dry and warm regions, is constituted by 40 per cent green water and 43 per cent blue water, the remainder referring to grey water (pollution of water). 
Accordingly, and as advanced by De Fraiture et al. (2004), this study corroborates that international trade in agricultural commodities has a positive net impact on global water use. This is because major exporters produce more efficiently than major importers and, in line with the present results, because major exporters produce under relatively favourable productive rain-fed conditions while most importers would have relied (at least partially) on irrigation (ibid.). Rain-fed agriculture, with some of the highest yields in several regions, holds great under-exploited potential for increasing water productivity through better water management practices gaining more yield and value from water (CAWMA, 2007). This is an effective means of intensifying agricultural production and reducing environmental degradation (ibid.). Only when trade results in a reduction of irrigation water depletion, is it proper to speak of "real" water savings (De Fraiture et al., 2004).

The volume of international trade in agricultural commodities is increasing faster than the global volume of production, pointing to a growth of international dependencies in food supply (Hoekstra and Chapagain, 2007a). Implicitly it also implies growing international water dependencies with regard to water supply (ibid.). By importing food, countries also import and save water in virtual form (Hoekstra and Chapagain, 2007a). Supporters of virtual water imports to water-scarce countries see interdependence between nations as a way to improve water resources management (Allan, 2003). However, virtual-water flows present a number of potential drawbacks. According to Hoekstra and Chapagain (2007a) these include reduced access to food by the poor, increased risk of environmental impact in exporting countries and moving away from food self-sufficiency. Self-sufficiency, though, is not an option for countries with rapidly expanding populations, especially if they are poor.

Virtual-water 'trade' between nations, based on the principle of comparative advantage in water availability, has the potential to improve global water use efficiency and to achieve water security in water-poor regions of the world (Hoekstra and Hung, 2005; Chapagain et al., 2006a). In this context, and in line with Allan (2006), the present findings reveal that the green water component of the virtual water embodied in international trade of agricultural commodities plays a major role in ensuring water security in water deficit economies. However, global green water is just one potential means of making water security possible for water scarce regions. Besides, the process can only operate effectively for the economies that achieve a level of socio-economic development to enable the trade in water intensive commodities (Allan, 2006). 


\section{Conclusion}

Within the context of recent studies on virtual-water trade, the present research critically evaluates the strategic importance and implications of green virtual water in relation to international crop trade. Even if traditionally emphasis has been given to the "miracle" of irrigation systems, today most global crop production is rain-fed (Falkenmark and Rockström, 2004). As well as having a lower opportunity cost, the use of green water in the production of crops is considered more sustainable than the use of blue water (Yang et al., 2006; Zygmunt, 2007). The optimality of virtual-water flows, thus, depends on whether, and how, green and/or blue water are used for crop production, determining the opportunity cost of the water being saved (Chapagain et al., 2006a).

Although green water represents the largest share of the virtual-water flows related to the international trade of agricultural commodities, with exports going from green water-rich countries towards generally blue water based ones, green water volumes have rarely been estimated. In this context, the present study corroborates that green water is by far the largest share of virtual water embodied in maize, soybean and wheat exports from the USA, Canada, Australia and Argentina during the period 2000-2004.

At the national level, green water losses in rain-fed based countries are positively evaluated in economic terms since green water use not only has a lower opportunity cost but it also causes less negative externalities than blue water use (Yang et al., 2006). However, even if in relatively small amounts, blue water continues to be exploited in the selected countries regardless of the negative externalities its use generates and in spite of its higher opportunity cost. National policies that link land/water management and introduce water pricing would achieve a more efficient allocation of water resources while avoiding wasteful outcomes (Falkenmark, 2003).

At the global level, previous studies roughly estimated that two thirds of the total volume of water used for crop production is green water (Rockström et al., 1999; Chapagain and Hoekstra, 2004; De Fraiture et al., 2004). The present research shows that green water amounts to about three quarters of the total virtual water embodied in major maize, soybean and wheat exports. Furthermore, by adding estimates for three different commodities, this study complements the work of Chapagain et al. (2006b) for cotton. Accordingly, and in line with De Fraiture et al. (2004), this study confirms that, if based on rain-fed crop production, international trade in agricultural commodities has the potential to reduce irrigation water demand. Accordingly, green water 'flows' can play a major role in ensuring water security in water deficit economies (Allan, 2006). However, green water is just one of several factors that contribute to water security. Other factors such as technology, the potential for further increases in the productivity of soil water and irrigation water, national food policies and international trade agreements also need to be considered (Hoekstra and Hung, 2005).

In conclusion, even if nowadays water is seldom the dominant factor determining 'trade' of water-intensive commodities, it can become increasingly important in a context of greater scarcity and demand (CAWMA, 2007). International green virtual-water 'trade' provides water-short countries with an option for ensuring water and food security. At present, however, this option is far from being fully exploited due to the absence of more virtual water-friendly international trade regimes with equal access to global markets. Other obstacles are 
formed by the inadequacy of water pricing structures worldwide and the agricultural subsidies in the EU and USA. Further, the low levels of socio-economic development and poverty of many economies impede these economies from availing of the virtual-water 'trade' solution (Allan, 2006). The importance of international green virtual-water 'trade' and its contribution to water security in the future will, therefore, depend on factors such as the productivity of blue and green water, water pricing, international trade agreements, the costs of engaging in trade, and the nature of domestic economic objectives and political considerations (CAWMA, 2007). 


\section{References}

Allan, J.A. (1997) 'Virtual water': a long term solution for water short Middle Eastern economies? Water Issues Group, School of Oriental and African Studies. University of London. London. Available from: www.soas.ac.uk/research/our_research/projects/waterissues/papers/38347.pdf [Accessed 16 January 2008]

Allan, J.A. (1999) Water stress and global mitigation: water food and trade. Arid Lands Newsletter. Available from: http://ag.arizona.edu/OALS/ALN/aln45/allan.html [Accessed 16 January 2008]

Allan, J.A. (2001) Virtual water -economically invisible and politically silent- a way to solve strategic water problems. International water and Irrigation 21 (4): 39-41.

Allan, J.A. (2003) Virtual Water- the water, food, and trade nexus useful concept or misleading metaphor? Water International 28 (1): 4-11.

Allan, J.A. (2006) Virtual Water, Part of an invisible synergy that ameliorates water scarcity. In Water Crisis: Myth or Reality? Ed. Rogers, Llamas and Martinez-Cortina. Balkema Publishers.

Allen, R.G., Pereira, L.S., Raes, D. and Smith, M. (1998) Crop evapotranspiration - Guidelines for computing crop water requirements - FAO Irrigation and drainage paper 56. Food and Agriculture Organization. Rome, Italy.

CAWMA (2007) Water for Food, Water for Life: A Comprehensive Assessment of Water Management in Agriculture. Earthscan. London.

Chapagain, A.K. and Hoekstra, A.Y. (2003) Virtual water flows between nations in relation to trade in livestock and livestock products. Value of Water Research Report Series No.13, UNESCO- IHE Delft, The Netherlands. Available from: www.waterfootprint.org/Reports/Report13.pdf [Accessed 16 January 2008]

Chapagain, A.K. and Hoekstra, A.Y. (2004) Water footprints of nations. Value of Water Research Report Series No.16, UNESCO- IHE. Delft, The Netherlands. Available from: www.waterfootprint.org/Reports/Report16Vol1.pdf [Accessed 16 January 2008]

Chapagain, A.K., Hoekstra, A.Y. and Savenije, H.H.G. (2006a) Water saving through international trade of agricultural products. Hydrology and Earth System Sciences 10: 455-468.

Chapagain, A.K., Hoekstra, A.Y., Savenije, H.H.G. and Gautam, R. (2006b) The water footprint of cotton consumption: An assessment of the impact of worldwide consumption of cotton products on the water resources in the cotton producing countries. Ecological Economics 60 (1): 186-203.

De Fraiture, C., Cai, X., Amarasinghe, U., Rosegrant, M. and Molden, D. (2004) Does International Cereal Trade Save Water? The Impact of Virtual Water Trade on Global Water Use. Comprehensive Assessment Research Report 4. Comprehensive Assessment Secretariat. Colombo, Sri Lanka. Available from: www.iwmi.cgiar.org/Assessment/FILES/pdf/publications/ResearchReports/CARR4.pdf [Accessed 16 January 2008]

De Fraiture, C., Giordano, M. and Yongsong, L. (2007) Biofuels and implications for agricultural water use: blue impacts of green energy. International Water Management Institute. Colombo, Sri Lanka. 
Available from: www.iwmi.cgiar.org/EWMA/files/papers/Biofuels\%20-\%20Charlotte.pdf [Accessed 16 January 2008]

Encyclopaedia Britannica (2007) Chicago, USA. Available from: www.britannica.com [Accessed 16 January 2008]

Falkenmark, M. (2003) Freshwater as shared between society and ecosystems: from divided approaches to integrated challenges. Philosophical Transactions of the Royal Society B: Biological Sciences 358 (1440): 2037-2049.

Falkenmark, M. and Rockström, J. (2004) Balancing water for humans and nature: The new approach in ecohydrology, Earthscan, London, UK.

FAO (2003a) CROPWAT Model. Food and Agriculture Organization. Rome, Italy. Available from: www.fao.org/nr/water/infores_databases_cropwat.html [Accessed 16 January 2008]

FAO (2003b) CLIMWAT Database. Food and Agriculture Organization. Rome, Italy. Available from: www.fao.org/nr/water/infores_databases_climwat.html [Accessed 16 January 2008]

FAO (2007a) AQUASTAT. Food and Agriculture Organization. Rome, Italy. Available from: www.fao.org/nr/water/aquastat/main/index.stm [Accessed 16 January 2008]

FAO (2007b) FAOSTAT Database. Food and Agriculture Organization. Rome, Italy. Available from: http://faostat.fao.org [Accessed 16 January 2008]

Foreign Affairs and International Trade Canada (2007) Fast Facts: North American Free Trade Agreement. Foreign Affairs and International Trade Canada. Ottawa.Available from: www.international.gc.ca/nafta-alena/NAFTA-fast-facts-en.asp [Accessed 16 January 2008]

Gerbens-Leenes, P.W., Hoekstra, A.Y. and Van der Meer, Th.H. (2008) Water footprint of bio-energy and other primary energy carriers, Value of Water Research Report Series No.29, UNESCO-IHE. Delft, The Netherlands.

Greenaway, D., Hassan, R. and Reed, G.V. (1994) An empirical analysis of comparative advantage in Egyptian agriculture. Applied Economics 26 ( 6): 649-657.

Hardin, G. (1968) The tragedy of the commons. Science 162 (13): 1243-1248.

Hoekstra, A.Y. (1998) Perspectives on water: An integrated model-based exploration of the future International Books. Utrecht.

Hoekstra, A.Y. (2003) (Ed.) Virtual water trade: Proceedings of the International Expert Meeting on Virtual Water Trade. Value of Water Research Report Series No.12, UNESCO-IHE. Delft, The Netherlands. Available from: www.waterfootprint.org/Reports/Report12.pdf [Accessed 16 January 2008]

Hoekstra, A.Y. (2007) Human appropriation of natural capital: comparing ecological footprint and water footprint analysis. Value of Water Research Report Series No. 23, UNESCO- IHE. Delft, The Netherlands. Available from: www.waterfootprint.org/Reports/Report23-Hoekstra-2007.pdf [Accessed 16 January 2008]

Hoekstra, A.Y. and Chapagain, A.K. (2007a) The water footprints of Morocco and the Netherlands: Global water use as a result of domestic consumption of agricultural commodities. Ecological Economics 64(1): 143-151. 
Hoekstra, A.Y. and Chapagain, A.K. (2007b) Water footprints of nations: water use by people as a function of their consumption pattern. Water Resources Management 21(1): 35-48.

Hoekstra, A.Y. and Chapagain, A.K. (2008) Globalization of water: Sharing the planet's freshwater resources. Blackwell Publishing. Oxford, UK.

Hoekstra, A.Y. and Hung, P.Q. (2002) Virtual water trade: a quantification of virtual water flows between nations in relation to international crop trade. Value of Water Research Report Series No. 11. UNESCO-IHE. Delft, The Netherlands. Available from: www.waterfootprint.org/Reports/Report11.pdf [Accessed 16 January 2008]

Hoekstra, A.Y. and Hung, P.Q. (2005) Globalisation of water resources: international virtual water flows in relation to crop trade. Global Environmental Change 15 (1): 45-56.

Ma, J., Hoekstra, A.Y., Wang, H., Chapagain, A.K. and Wang, D. (2006) Virtual versus real water transfers within China. Philosophical Transactions of the Royal Society (361): 835-842.

Nakayama, M. (2003) Implications of virtual water concept on management of international water systems - cases of two Asian international river basins. In Virtual water trade: Proceedings of the International Expert Meeting on Virtual Water Trade, Value of Water Research Report Series, No. 12, A.Y. Hoekstra (Ed.), UNESCO-IHE, Delft, The Netherlands.

Oki, T. and Kanae, S. (2004) Virtual water trade and world water resources. Water Science and Technology 49(7): 203-209.

Ostrom, E. (1990) Governing the commons: the evolution of institutions for collective action. Cambridge University Press. Cambridge.

Rockström, J. (2001) Green water security for the food makers of tomorrow: windows of opportunity in drought-prone savannahs Water Science and Technology 43 (4): 71-78.

Rockström, J., Gordon, L., Folke, C., Falkenmark, M. and Engwall, M. (1999) Linkages among water vapor flows, food production and terrestrial ecosystem services. Conservation Ecology 3 (2): 1-5.

Rockström, J., Lannerstad, M., and Falkenmark, M. (2007) Assessing the water challenge of a new green revolution in developing countries. PNAS 104(15): 6253-6260.

Rosegrant, M., Cai, X. and Cline, S. (2002) World water and food to 2025. International Food Policy Research Institute (IFPRI). Washington D.C.

SAGPyA (2007) Secretaría de Agricultura, Ganadería, Pesca y Alimentos - Estimaciones agrícolas. Buenos Aires. Available from: www.sagpya.mecon.gov.ar [Accessed 16 January 2008]

Seckler, D., Molden, D., Amarasinghe, U. and Fraiture, C. (2000) Water Issues for 2025: A research perspective. IWMI's contribution to the $2^{\text {nd }}$ World Water Forum. Colombo, Sri Lanka: International Water Management Institute.

Statistics Canada (2007) Canada's National Statistical Agency. Ottawa, Ontario. Available from: www.statcan.ca [Accessed 16 January 2008]

USDA (2006) Major World Crop Areas and Climatic Profiles. United States Department of Agriculture. Washington, D.C., United States. Available from: www.usda.gov/oce/weather/pubs/Other/MWCACP/index.htm [Accessed 16 January 2008] 
USDA (2007) USDA National Agricultural Statistics Service - Quick Stats - U.S. \& All States Data -

Crops . Washington DC. Available from: www.nass.usda.gov/QuickStats/Create_Federal_All.jsp [Accessed 16 January 2008]

USDA/ERS (2007) Briefing Rooms - Irrigation and Water Use. United States Department of Agriculture,

Economic Research Service. Washington DC. Available from: www.ers.usda.gov/briefing/wateruse [Accessed 16 January 2008]

USDA-FAS (2007) Australia Wheat. United States Department of Agriculture - Foreign Agricultural

Service Washington DC. Available from:

www.fas.usda.gov/pecad2/highlights/2000/12/aswheat/as_wht0012.htm\#DATABASE\%20STATIST

ICS [Accessed 16 January 2008]

Van Hofwegen, P. (2005) Virtual water: Conscious choices. Voices on Virtual Water. World Water

Council. Available from:

www.worldwatercouncil.org/fileadmin/wwc/Programs/Virtual_Water/Virtual_Water_voices.pdf [Accessed 16 January 2008]

Wichelns, D. (2001) The role of 'virtual water' in efforts to achieve food security and other national goals, with an example from Egypt. Agricultural Water Management 49: 131-151.

Yang, H., Wang, L., Abbaspour, K.C. and Zehnder, A.J.B. (2006) Virtual water trade: an assessment of water use efficiency in the international food trade. Hydrology and Earth System Sciences 10: 443454.

Zygmunt, J. (2007) Hidden Waters. Waterwise. London, UK. Available from:

www.waterwise.org.uk/images/site/EmbeddedWater/hidden\%20waters\%2C\%20waterwise $\% 2 \mathrm{C} \% 20 \mathrm{f}$ ebruary\%202007.pdf [Accessed 16 January 2008] 


\section{Value of Water Research Report Series}

Editorial board:

Arjen Y. Hoekstra - University of Twente, a.y.hoekstra@utwente.nl

Hubert H.G. Savenije - Delft University of Technology, h.h.g.savenije@,tudelft.nl

Pieter van der Zaag - UNESCO-IHE Institute for Water Education, p.vanderzaag@unesco-ihe.org

Reports are downloadable from www.waterfootprint.org

1. Exploring methods to assess the value of water: A case study on the Zambezi basin.

A.K. Chapagain - February 2000

2. Water value flows: A case study on the Zambezi basin.

A.Y. Hoekstra, H.H.G. Savenije and A.K. Chapagain - March 2000

3. The water value-flow concept.

I.M. Seyam and A.Y. Hoekstra-December 2000

4. The value of irrigation water in Nyanyadzi smallholder irrigation scheme, Zimbabwe.

G.T. Pazvakawambwa and P. van der Zaag - January 2001

5. The economic valuation of water: Principles and methods

J.I. Agudelo - August 2001

6. The economic valuation of water for agriculture: A simple method applied to the eight Zambezi basin countries J.I. Agudelo and A.Y. Hoekstra - August 2001

7. The value of freshwater wetlands in the Zambezi basin I.M. Seyam, A.Y. Hoekstra, G.S. Ngabirano and H.H.G. Savenije-August 2001

8. 'Demand management' and 'Water as an economic good': Paradigms with pitfalls H.H.G. Savenije and P. van der Zaag - October 2001

9. Why water is not an ordinary economic good H.H.G. Savenije - October 2001

10. Calculation methods to assess the value of upstream water flows and storage as a function of downstream benefits I.M. Seyam, A.Y. Hoekstra and H.H.G. Savenije - October 2001

11. Virtual water trade: A quantification of virtual water flows between nations in relation to international crop trade A.Y. Hoekstra and P.Q. Hung - September 2002

12. Virtual water trade: Proceedings of the international expert meeting on virtual water trade A.Y. Hoekstra (ed.) - February 2003

13. Virtual water flows between nations in relation to trade in livestock and livestock products A.K. Chapagain and A.Y. Hoekstra - July 2003

14. The water needed to have the Dutch drink coffee A.K. Chapagain and A.Y. Hoekstra-August 2003

15. The water needed to have the Dutch drink tea A.K. Chapagain and A.Y. Hoekstra-August 2003 
16. Water footprints of nations

Volume 1: Main Report, Volume 2: Appendices

A.K. Chapagain and A.Y. Hoekstra - November 2004

17. Saving water through global trade

A.K. Chapagain, A.Y. Hoekstra and H.H.G. Savenije - September 2005

18. The water footprint of cotton consumption

A.K. Chapagain, A.Y. Hoekstra, H.H.G. Savenije and R. Gautam-September 2005

19. Water as an economic good: the value of pricing and the failure of markets

P. van der Zaag and H.H.G. Savenije - July 2006

20. The global dimension of water governance: Nine reasons for global arrangements in order to cope with local water problems

A.Y. Hoekstra - July 2006

21. The water footprints of Morocco and the Netherlands

A.Y. Hoekstra and A.K. Chapagain-July 2006

22. Water's vulnerable value in Africa

P. van der Zaag - July 2006

23. Human appropriation of natural capital: Comparing ecological footprint and water footprint analysis A.Y. Hoekstra - July 2007

24. A river basin as a common-pool resource: A case study for the Jaguaribe basin in Brazil P.R. van Oel, M.S. Krol and A.Y. Hoekstra - July 2007

25. Strategic importance of green water in international crop trade M.M. Aldaya, A.Y. Hoekstra and J.A. Allan-March 2008

26. Global water governance: Conceptual design of global institutional arrangements M.P. Verkerk, A.Y. Hoekstra and P.W. Gerbens-Leenes - March 2008

27. Business water footprint accounting: A tool to assess how production of goods and services impact on freshwater resources worldwide

P.W. Gerbens-Leenes and A.Y. Hoekstra-March 2008

28. Water neutral: reducing and offsetting water footprints

A.Y. Hoekstra-March 2008

29. Water footprint of bio-energy and other primary energy carriers

P.W. Gerbens-Leenes, A.Y. Hoekstra and Th.H. van der Meer-March 2008

30. Food consumption patterns and their effect on water requirement in China

J. Liu and H.H.G. Savenije - March 2008

31. Going against the flow: A critical analysis of virtual water trade in the context of India's National River Linking Programme

S. Verma, D.A. Kampman, P. van der Zaag and A.Y. Hoekstra-March 2008 

UNESCO-IHE

P.O. Box 3015

2601 DA Delft

The Netherlands

Website www.unesco-ihe.org

Phone +31152151715

University of Twente

Delf University of Technology
UNESCO-IHE

Institute for Water Education

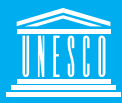

\section{University of Twente The Netherlands}

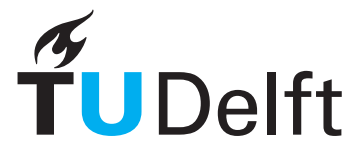

Delft University of Technology 